\title{
Research on the Influence of Social Capital on the Entrepreneurial Performance in the Small Micro-Enterprises
}

\author{
Jinfeng Wang ${ }^{1,2}$, Heyu Chang ${ }^{1}$ and Weinan $\mathrm{Li}^{1}$ \\ ${ }^{1}$ Management Engineering Institute, Zhengzhou University, Gaoxin District, Zhengzhou, Henan Province, \\ China \\ ${ }^{2}$ Economic and Management Institute, Shanghai Maritime University, Shanghai, China
}

1406987621@qq.com; okaychy@163.com; 2278906722@qq.com

Keywords: Small micro-enterprise; Social capital; Entrepreneurial performance

\begin{abstract}
Small micro-enterprise, as an important force in scientific and technological innovation, has an essential strategic significance on maintaining steady and rapid economic development. This paper, taking the small micro-enterprise as the target group, combines both theoretical exploration and demonstration analysis to study the entrepreneurial opportunities recognition from the perspective of social capital. The small micro-enterprises' social capital contains structural dimension, relational dimension and cognitive dimension, and the entrepreneurial performance includes survival and growth performance. In this paper, SPSS20.0 and AMOS19.0 are used to conduct reliability analysis, structure equation modelling and hypothesis test. Results from the survey are as follows: Structural and relational dimension of social capital has a significantly positive impact on entrepreneurial performance while the positive influence of cognitive dimension on growth performance is not significant. In the end, this study puts forward some proposals in order to achieve the growth of enterprise value and entrepreneurial performance.
\end{abstract}

\section{Introduction}

The term "Small micro-enterprise" is put forward by the famous economist Professor Lang Xianping, which is the name for a group of small and medium-sized enterprises, micro enterprises, family owned enterprises, individual industrial and commercial households. In China, almost 90\% of the enterprises belong to areas of small and micro businesses. Small micro-enterprise not only provide jobs and raise incomes, but also spurs growth through starting a business, so it has a positive significance to promote social stability. However, the annual average survival rate of new small micro-enterprise is generally low, for the success rate is only about $30 \%$.

Talking about the concept of entrepreneurial work, the entrepreneurial performance is the core element that cannot be ignored. It is a key indicator to measure entrepreneurial achievements. Entrepreneurial performance point out the way to get the future growth for small micro-enterprises. It's believe that measuring entrepreneurial performance is very necessary for judging whether the entrepreneurial activity in small micro-enterprise is success or not (Low and Macmillan, 1988).

In addition, the social capital of entrepreneurs also plays an important role in entrepreneurial performance. Chinese in such a traditional network oriented economy, entrepreneurs should give full play to their social relations, and the social capital has become one of the main factors that affecting the performance of small micro-enterprise and each part of the entrepreneurial process. Therefore, in this particular case, studying the entrepreneurial social capital has great significance on promoting entrepreneurial performance and expanding the business scope.

The research significance is that: On the one hand, as an important asset of small microenterprise, social capital has positive effects on obtaining external resources, building competitive advantage and improving business performance. Although most scholars have identified with the influence of social capital on entrepreneurial performance of small micro-enterprise, the effect of every dimensions of social capital on entrepreneurial performance has not been unified. This paper not only study the impact of social capital of small micro-enterprise on entrepreneurial performance, 
but also using empirical analysis method demonstrates the effect of all the dimensions of social capital on entrepreneurial performance in small micro-enterprise. The research conclusion extends and renews the relative fields, and enriches the influence of theory of social capital and entrepreneurial performance.

On the other hand, small micro-enterprise is an important force in China's economic development, and the research on entrepreneurial performance can effectively measure its future development prospects. This paper takes small micro-enterprise as research objects and surveys the empirical research of the impact of social capital on entrepreneurial performance, so the research conclusion can play a better guide for small micro-enterprise to increase employment and improve people's lives.

\section{Literature Review}

\subsection{Relevance theory of social capital \\ 2.1.1 Definition of social capital}

In 1986, the French scientist first introduced a new concept of social capital, he emphasized the social capital will have a more important role in the development of social economy as time goes by (Bourdieu, 1986). After this, the study on social capital began to gradually rise.

Tsai (2003) combined the social capital with enterprise, and found that strengthening the relationship between the social network that can help enterprises to survive and develop in the competition; Glaeser (2002) proposed enterprise social capital is a kind of economic resources, those resources can promote the enterprise development; Coleman (1990) believed that social capital can help action subject achieve its goal; Wever (2005) argued that enterprise social capital is the resource which based on social network; Putnan (1995) believed that the essence of social capital is the relationship network, and it is an important source of enterprise knowledge, information and support; Leana and Buren (1999) considered that the social capital theory has already extended to the collective social capital, it can not only make the individual benefit, but also can assists organizations. Therefore, through a long-term exploration, an increasing number of scholars argue that social capital has gone beyond the economic capital, it is a resource that can make profits for the company on the basis of physical capital and human capital. Please remember that all the papers must be in English and without orthographic errors.

\subsubsection{Social Capital Measurement}

According to the concept of social capital, it can be found that the content of social capital is rich and variable, and it exists in the social structure of individual and organization. Therefore, it has become a universal consensus of scholars that social capital involves multi-dimensional characteristics. Nahapiet and Ghoshal (2000) believed that the enterprise social capital is divided into structural dimension, relational dimension and cognitive dimension; Labianca (2006) divided social capital into with formal and informal relational networks; The division mode of Adler (2002) on social capital is roughly identical to the Nahapiet, and they pointed out that the structural dimension, relational dimension and cognitive dimension of social capital reflected the contact of social interaction opportunities, exchange willingness and cognitive ability respectively for each action subject. Currently, many scholars argue that it is acceptable to represent the social capital with three dimensions that are shown as follows:

(1) Structural dimension of social capital. It is mainly refers to the overall network organization. And the social capital can be measured by the analysis of the individual groups and the relationship between each entity. It's believed that social network relation is conducive to improving the efficiency of cooperation (Coleman, 1990).

(2) Relational dimension of social capital. It emphasizes on access to resource through coordinating the bidirectional relationship. It's believed that individuals can obtain social capital through taking advantage of other people's information and status, or the various functional social relations, and the stronger the social capital is, the more resources the individual get (Nahapiet and Ghoshal, 2000).

(3) Cognitive dimension of social capital. It refers to the consensus degree of the cognition and 
view of all individuals regard to the same thing. And it's argued that the common language will shorten the distance between people, and then make people more closer and easy to communicate (Nahapiet and Ghoshal, 2000).

\subsection{Relevance theory of entrepreneurship}

\subsubsection{Definition of entrepreneurship}

Entrepreneurship is a complex phenomenon across multiple disciplines. It shows the features of diversity. Knight (2013) pointed out that entrepreneurship is an effective way to predict the future activities; Mair (2001) argued that the entrepreneurship means through using various resources effectively, the entrepreneur can actively take the initiative to complete a series of business activities; Ning and Wang (2001) pointed out that entrepreneurship can create economic value and social value for the enterprise.

\subsubsection{Definition of entrepreneurial performance}

Because scholars have different perspectives on entrepreneurial performance, and lack of mature theory to guide the selection of entrepreneurial performance indicators, therefore, how to evaluate the results of entrepreneurship is still not united.

Covin and Slevin (1991) pointed out that the entrepreneurial performance measurement should includes growth indicators and profitability indicators. Among them, the growth index includes market share, enterprise production scale, the number of employees and so on; the profitability indicators include the return on assets (ROA), target rate of profit and so on. Cooper (1994) argued that the satisfaction of entrepreneurs can be used to evaluate the entrepreneurial performance; Muprhy (2014) pointed out that the efficiency of growth and the profit can be used as standard to measure the dimensions of entrepreneurial performance; Chrisman (1998) that entrepreneurial performance can be divided into survival and growth performance. This division are recognized by most of pioneering researchers, but the specific operation method and measurement standard is not unified; Rong (2007) proposed a multidimensional model of entrepreneurial performance and its index evaluation system includes the indicators such as income, profit, employee commitment and customer loyalty and so on; Cao (2011) constructed the generation, growth and reputation model of entrepreneurial performance, and verified the reliability of the model through empirical analysis.

\section{Research Design}

\subsection{Research Model}

Scholars have studied the impact of social capital on entrepreneurial performance from different aspects as well as the influence on transmission mechanism of entrepreneurial performance of social capital in the small micro-enterprise. Due to the multiple dimension and multifactorial characteristics of entrepreneurial performance, so it also determines the entrepreneurial performance is determined by many factors. Social capital is a multidimensional concept and its important influence on entrepreneurial performance has been confirmed by many scholars, and it has been demonstrated that different dimension of social capital have diverse effects on entrepreneurial performance. The influence of social capital on entrepreneurial performance may be indirect, so the function of external factors worked at entrepreneurial behavior may depend on the internal cause. Lack of resources is very common in the early stage of the small micro-enterprise, so the degree of dependence on social resources will be relatively large, which also has a great impact on entrepreneurial performance.

Based on the literature review, it can be found that the more social capital entrepreneur possessed, the more help they can obtained from external support. And based on those supports, the social capital will enable enterprises to better access to resources and improve the entrepreneurial performance. The specific research hypotheses model is illustrated as shown in Figure 1. 


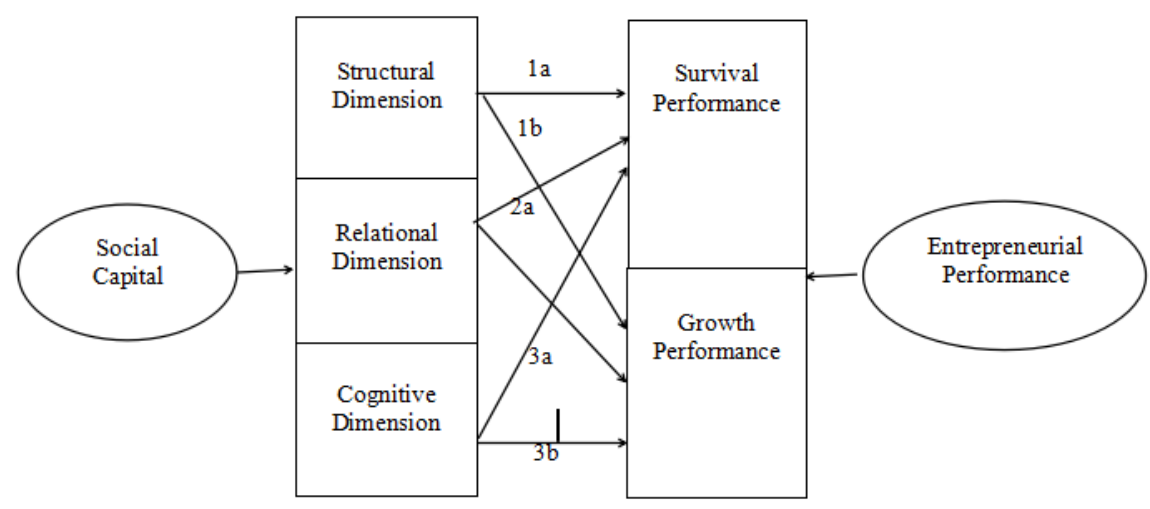

Fig.1 Hypothesis model

\subsection{Research Hypothesis}

Entrepreneurs depend on their own social capital not only can lower the cost of access to resources, but also can acquire scarce resources that could be very difficult to obtain. It's adopted the dimension of small micro-enterprise's social capital that Nahapiet and Ghoshal classified which includes the relationship dimension, structural dimension and cognitive dimension, and divided entrepreneurial performance into survival performance, growth performance and successful performance (Lusheng, 2010). After that, he verified the relationship between the various dimensions of social capital and the diverse dimensions of entrepreneurial performance respectively; Xin (2010) studied the relation of entrepreneurial performance to human capital and social capital in empirical research, and she found that the entrepreneur's social capital has a significant impact on the entrepreneurial performance; Chen and Zheng (2017) studied the relation of entrepreneurial performance to entrepreneur's knowledge base and social capital and found that there are positive effects between entrepreneurial performance and social capital.

At present, most of the scholars agree with the view that enterprise's social capital and entrepreneurial performance influence relationship. But their opinions about the impact of different dimensions of social capital on entrepreneurial performance are inconsistent, so the future research from larger studies is needed to verify this link. Based on what has been mentioned above, this paper put forward those assumptions:

H1a: The structural dimension of social capital in small micro-enterprise have a significantly positive influence on enterprise survival performance;

H1b: The structural dimension of social capital in small micro-enterprise have a significantly positive influence on enterprise growth performance;

H2a: The relational dimension of social capital in small micro-enterprise have a significantly positive influence on enterprise survival performance;

H2b: The relational dimension of social capital in small micro-enterprise have a significantly positive influence on enterprise growth performance;

H3a: The cognitive dimension of social capital in small micro-enterprise have a significantly positive influence on enterprise survival performance;

H3b: The cognitive dimension of social capital in small micro-enterprise have a significantly positive influence on enterprise growth performance. 


\section{Empirical Research}

\subsection{Questionnaire Design}

Table 1: Measurement of entrepreneurial performance and social capital dimensions in small microenterprise.

\begin{tabular}{|c|c|c|c|}
\hline \multirow{8}{*}{$\begin{array}{l}\text { Entrepreneurial } \\
\text { performance of small } \\
\text { micro-enterprise }\end{array}$} & \multirow{4}{*}{$\begin{array}{c}\text { Survival } \\
\text { performance }(\mathrm{S})\end{array}$} & $\begin{array}{l}\text { At present, the enterprise survival } \\
\text { condition is good }\end{array}$ & S1 \\
\hline & & $\begin{array}{l}\text { The enterprise will continue to } \\
\text { operate for at least } 5 \text { years }\end{array}$ & $\mathrm{S} 2$ \\
\hline & & $\begin{array}{l}\text { The enterprise is good at dealing } \\
\text { with the survival crisis }\end{array}$ & S3 \\
\hline & & Customer satisfaction is high & S4 \\
\hline & \multirow{4}{*}{$\begin{array}{c}\text { Growth } \\
\text { performance (C) }\end{array}$} & $\begin{array}{c}\text { The speed of new product } \\
\text { development }\end{array}$ & $\mathrm{C} 1$ \\
\hline & & The new product sales ratio & $\mathrm{C} 2$ \\
\hline & & The number of patent applications & $\mathrm{C} 3$ \\
\hline & & The number of new products & $\mathrm{C} 4$ \\
\hline \multirow{9}{*}{$\begin{array}{l}\text { Social capital of small } \\
\text { micro-enterprise }\end{array}$} & \multirow{3}{*}{$\begin{array}{c}\text { Structural } \\
\text { dimension }(\mathrm{J})\end{array}$} & The depth of relationships & $\mathrm{J} 1$ \\
\hline & & The frequency of relationships & $\mathrm{J} 2$ \\
\hline & & The number of contact & J3 \\
\hline & \multirow{3}{*}{$\begin{array}{c}\text { Relational } \\
\text { dimension (G) }\end{array}$} & Mutually keep faith & G1 \\
\hline & & The tendency of selfish & G2 \\
\hline & & Sincerely cooperate & G3 \\
\hline & \multirow{3}{*}{$\begin{array}{c}\text { Cognitive } \\
\text { dimension }(R)\end{array}$} & Oneness of purpose & $\mathrm{R} 1$ \\
\hline & & Communication effectively & $\mathrm{R} 2$ \\
\hline & & Similar values & R3 \\
\hline
\end{tabular}

The questionnaire consists of three parts: the small micro-enterprise's basic information, and measurement of three dimensions of social capital in the small micro-enterprise and the measurement of entrepreneurial performance in two dimensions. Among them, the entrepreneurial performance is divided into two dimensions: survival performance and growth performance, and 8 items were set to measure these two dimensions. The social capital is divided into three dimensions: structural dimension, relational dimension and cognitive dimension, and9 items were set to measure these three dimensions. The specific dimensions are shown in Table 1.

\subsection{Data Sources}

The investigation object of this questionnaire is mainly aimed at those small micro-enterprise entrepreneurs. In order to provide the data support for this study, the data collection began on April 1st and lasted into June 20th in XX province. In the end, there are 218 questionnaire responses were collected, 212 effective questionnaires have been got, and the effectiveness rate of this survey is $97 \%$.

It can be seen from the small micro-enterprise's basic information: in the perspective of the entrepreneur' gender, men accounted for $74.5 \%$ and women accounted for $25.5 \%$, it means entrepreneurs tend to be men; from the entrepreneur's age perspective, 16-25 years old accounted for $5.2 \%$, 26-35 years old accounted for 50.5\%, 36-45 years old accounted for $27.4 \%$ and more than 45 years old accounted for about 16.9\%; from the educational background perspective, the entrepreneurs are mainly undergraduate degree and junior college degree, accounted for $75 \%$, the master degree or above accounted for $14.2 \%$, and high school education and less accounted for only about $10 \%$. 


\subsection{Reliability Analysis}

By Cronbach's Alpha analysis, the questionnaire reflects high reliability and internal consistency as shown in Table 2. The report shows the Cronbach's Alpha of entrepreneurial performance and social capital in small micro-enterprise is 0.944 and 0.971 respectively, which means this questionnaire has a strongly internal consistency.

Table 2: Reliability analysis of entrepreneurial performance and social capital.

\begin{tabular}{|c|c|c|}
\hline Cronbach's Alpha & $\begin{array}{c}\text { Standardized } \\
\text { Cronbachs Alpha }\end{array}$ & $\begin{array}{c}\text { The number } \\
\text { of items }\end{array}$ \\
\hline .944 & .944 & 8 \\
\hline .971 & .971 & 9 \\
\hline
\end{tabular}

\subsection{Structural Equation Analysis}

This paper analyzes the collected data by using structural equation model to verify whether the model hypothesis is correct. This paper regards the social capital and entrepreneurial performance as latent variables, and using the method of structural equation model to find their relationships. The structural equation is shown as follows:

$$
\begin{gathered}
J=j_{1} J_{1}+j_{2} J_{2}+j_{3} J_{3}+\varepsilon_{1} \\
G=g_{1} G_{1}+g_{2} G_{2}+g_{3} G_{3}+\varepsilon_{2} \\
R=r_{1} R_{1}+r_{2} R_{2}+r_{3} R_{3}+\varepsilon_{3} \\
S=s_{1} S_{1}+s_{2} S_{2}+s_{3} S_{3}+s_{4} S_{4}+\varepsilon_{4} \\
C=c_{1} C_{1}+c_{2} C_{2}+c_{3} C_{3}+c_{4} C_{4}+\varepsilon_{5} \\
\alpha_{1} J+\alpha_{2} G+\alpha_{3} R+\varepsilon_{6}=\beta_{1} S+\beta_{2} C
\end{gathered}
$$

Among them, J, G, R represent the latent variables of social capital which contains three dimensions: structural dimension, relational dimension and cognitive dimension; and S, C represent the latent variables of entrepreneurial performance which includes two dimensions: survival performance and growth performance.The table below is the goodness of fit of the model evaluation index, which aimed to evaluate the overall goodness of fitting model. The specific goodness-of-fit statistics is illustrated as shown in Table 3.

Table 3: The analysis of goodness of fit of the model.

\begin{tabular}{|c|c|c|}
\hline $\begin{array}{c}\text { Evaluation index of } \\
\text { goodness of fit }\end{array}$ & Experience standard & Model \\
\hline $\begin{array}{c}\text { CMINDF } \\
(\mathrm{p}>0.05)\end{array}$ & $<3(\mathrm{p}>0.05)$ & 2.153 \\
\hline GFI & The closer to 1, the better to fit & 0.836 \\
\hline AGFI & The closer to 1, the better to fit & 0.747 \\
\hline CFI & The closer to 1, the better to fit & 0.812 \\
\hline YLI & The closer to 1, the better to fit & 0.793 \\
\hline IFI & The closer to 1, the better to fit & 0.887 \\
\hline RMSEA & $<0.1$ & 0.026 \\
\hline
\end{tabular}


Table 4: Model path coefficient and significant relations.

\begin{tabular}{|c|c|c|c|}
\hline Relations among variables & $\begin{array}{c}\text { P-value } \\
(\mathrm{P}<0.05)\end{array}$ & Significance & $\begin{array}{c}\text { Path } \\
\text { coefficient }\end{array}$ \\
\hline $\begin{array}{c}\text { Structural dimension vs } \\
\text { Survival performance }\end{array}$ & $* * *$ & Significant & 0.27 \\
\hline $\begin{array}{c}\text { Structural dimension vs } \\
\text { Growth performance }\end{array}$ & $* * *$ & Significant & 0.46 \\
\hline $\begin{array}{c}\text { Relational dimension vs } \\
\text { Survival performance }\end{array}$ & $* * *$ & Significant & 0.28 \\
\hline $\begin{array}{c}\text { Relational dimension vs } \\
\text { Growth performance }\end{array}$ & $* * *$ & Significant & 0.34 \\
\hline $\begin{array}{c}\text { Cognitive dimension vs } \\
\text { Survival performance }\end{array}$ & $* * *$ & Insignificant & 0.51 \\
\hline $\begin{array}{c}\text { Cognitive dimension vs } \\
\text { Growth performance }\end{array}$ & 0.246 & & \\
\hline
\end{tabular}

It can be seen from the table 3, the overall goodness of fit of the research model is quite good. In addition, analyzing the impact of small micro-enterprise's social capital on entrepreneurial opportunity recognition behavior is mainly based on analyzing the path coefficients in the structural equation model (by using the AMOS software 19.0). In the structural equation model, if $\mathrm{P}>0.95$, the path coefficient can be identified as significant. The path coefficient and the significant relations among variables is illustrated by AMOS 19.0 software analysis, and the result is shown in Table 4 .

\subsection{Hypothesis Result Analysis}

Based on table 4, the inspection of each hypothesis is shown in Table 5:

Table 5: Hypothesis testing.

\begin{tabular}{|c|l|l|}
\hline Hypothesis number & \multicolumn{1}{|c|}{ Hypothesis content } & Conclusion \\
\hline H1a & $\begin{array}{l}\text { H1a: The structural dimension of social capital in } \\
\text { small micro-enterprise have a significantly positive } \\
\text { influence on enterprise survival performance }\end{array}$ & \multicolumn{1}{c|}{$\begin{array}{c}\text { Hypothesis } \\
\text { established }\end{array}$} \\
\hline H1b & $\begin{array}{l}\text { The structural dimension of social capital in small } \\
\text { micro-enterprise have a significantly positive } \\
\text { influence on enterprise growth performance }\end{array}$ & Hypothesis established \\
\hline H2a & $\begin{array}{l}\text { The relational dimension of social capital in small } \\
\text { micro-enterprise have a significantly positive } \\
\text { influence on enterprise survival performance }\end{array}$ & Hypothesis established \\
\hline H2b & $\begin{array}{l}\text { The relational dimension of social capital in small } \\
\text { micro-enterprise have a significantly positive } \\
\text { influence on enterprise growth performance }\end{array}$ & Hypothesis established \\
\hline H3a & $\begin{array}{l}\text { The cognitive dimension of social capital in small } \\
\text { micro-enterprise have a significantly positive } \\
\text { influence on enterprise survival performance }\end{array}$ & Hypothesis established \\
\hline H3b & $\begin{array}{l}\text { The cognitive dimension of social capital in small } \\
\text { micro-enterprise have a significantly positive } \\
\text { influence on enterprise growth performance }\end{array}$ & $\begin{array}{l}\text { Hypothesis } \\
\text { unestablished }\end{array}$ \\
\hline
\end{tabular}

It can be seen from the table 5:

(1) The structural dimension of social capital in small micro-enterprise have a significantly positive influence on entrepreneurial performance

Hypothesis 1a was established, which means the social interaction and close degree of small micro-enterprise will promote entrepreneur's social capital, which will help enterprise to deal with all kinds of survival pressure in good condition, and meet customer requirements as well as continue to operate for at least 5 years in a certain extent; The establishment of the hypothesis $1 \mathrm{~b}$ 
shows that the structure dimension of social capital will help small and micro-enterprise to map out a pathway for the future, improve the the speed of producing new product and sales pace, and enhance their competitive advantage by improving the number of patents and products.

(2) The relational dimension of social capital in small micro-enterprise have a significantly positive influence on entrepreneurial performance

Hypothesis 1a was established, which means the entrepreneur's personal credit and sincerityoriented enterprise culture will improve the loyalty and reliability between small micro-enterprise and its stakeholders, and help enterprise to deal with all kinds of survival pressure in good condition, and meet customer requirements as well as to continue operating in a certain extent; The establishment of the hypothesis $1 \mathrm{~b}$ shows that the relational dimension of social capital will help small and micro-enterprise to expand social relations and get more space and opportunities for cooperation possibilities with colleagues or potential partners.

(3) The cognitive dimension of social capital in small micro-enterprise have a significantly positive influence on entrepreneurial performance

Hypothesis 3a was established, which means the consistent target, effective communication mechanism and similar values can enhance the depth of cooperation between small micro-enterprise with other companies, and the cognitive dimension of social capital will help enterprise to deal with all kinds of survival pressure in good condition, and to satisfy customer requirements as well as to achieve sustainable performance growth; The hypothesis $3 \mathrm{~b}$ is unestablished because of the small micro-enterprise this paper surveyed are mostly in the start-up stage, which means the cognitive dimension needs to be established on the basis of the stable relationship in a long term. Therefore, the influence of cognitive dimension can not be reflected on the entrepreneurial performance growth in a short term.

\section{Conclusions and suggestion}

\subsection{Conclusions}

This paper taking small micro-enterprise as the target group, using the method of combination of theoretical research and empirical research to construct the hypothesis model within the social capital and entrepreneurial performance. Among them, the social capital in the small microenterprise is divided into three dimensions: structural dimension, relational dimension and cognitive dimension; and the entrepreneurial performance is divided into two dimensions: survival performance and growth performance. And then, this paper collected data by questionnaire surveys, and used SPSS 20.0 and AMOS 19.0 for reliability test, structural equation model as well as hypothesis testing.

The results show that the influence of the social capital of structural dimension, relational dimension and cognitive dimension on entrepreneurial performance in the small micro-enterprise are basically significant positive (except the effect of cognitive dimension on growth performance). The specific results are as follows: the increase in structural dimension of social capital will help small micro-enterprise to translate this invisible social capital into real sales and production number; the expansion of the entrepreneur's social network scale and the increase in the member quantity will significantly improve the cooperation opportunities of obtaining effective market information for entrepreneurs; the increase in cognitive dimension of social capital will provide the superior environment for the enterprise's future development, which can also help entrepreneurs to get along with others in harmony and to promote the common language and common attributes among suppliers, vendors, government and other partners. However, the small micro-enterprise this paper surveyed are mostly in the start-up stage, because the cognitive dimension needs to be established on the basis of the stable relationship in a long term, so the influence of cognitive dimension can not be reflected on the entrepreneurial performance growth in a short term. Therefore, the increase in structural dimension, relational dimension and cognitive dimension of social capital can generally improve the entrepreneurial performance of small micro-enterprise.

\subsection{Suggestions}

The entrepreneurs are the core character of one enterprise, their level of social capital often plays 
an important role in the enterprise's survival and development. Based on the results of empirical research, it can be found that the social capital of small and micro-enterprise can affect the entrepreneurial performance positively. Therefore, in view of the above-mentioned facts, the author have the following suggestions:

The measurements of enhancing the structural dimension of social capital in small microenterprise: strengthening government relationships; actively participating in business counseling and training; establishing cooperative relations with universities and research institutions; strengthening the cooperative relations with other small micro-enterprises; improving the interaction with customers and suppliers. The entrepreneurs should keep close contact with the main communication subject, actively participate in formal and informal business activities, and constantly develop more heterogeneous social networks.

The measurements of enhancing the relational dimension of social capital in small microenterprise: establishing consistent goals with cooperation institution; learning actively from the company with excellent culture construction experience; advocating the use of common language. In order to eliminate unnecessary scruples, the entrepreneurs should establish a positive relationship with multiple subjects and actively participate in various activities.

The measurements of enhancing the cognitive dimension of social capital in small microenterprise: strengthening cooperation with the inter agency contact; cultivating the cooperation faith of honesty and mutual trust; establishing a long-term stable cooperative relations with cooperative institution. It is important to pay attention to the enterprise reputation, earnestly fulfill the commitments, actively integrate the social circles, and try to maintain the consistency between the internal value of enterprise and its partners.

\subsection{Prospect}

The future research can be improved from these aspects: First, the questionnaire results basically meet the study requirements, but because of the diversion and limitation of the industry, scale as well as geographical restrictions in small micro-enterprise, the representation of selected samples are affected to a certain extent, so the future research should focus on solving this problem; Second, some of the data is not satisfied perhaps due to the lack of variable selection accuracy, so the further study on the selection of these variables can be studied.

\section{References}

[1] Low, Murray B., and Macmillan, I. C., 1988. Macmillan. Entrepreneurship: Past Research and Future Challenges *. Entrepreneurship. Springer Berlin Heidelberg, p.139-161.

[2] Bourdieu, P., 1986. Forms of capital. Handbook of Theory \& Research for the Sociology of Education. Westport, CT: Greenwood Press.

[3] Tsai, and Wenpin., 2003. Social networks and organizations. London: Sage Publications.

[4] Glaeser E L. etal., 2002. An Economic Approach to Social Capital. Economic Journal, 112(483), p.437-458.

[5] Coleman, and James., 1990. Foundations of social theory. Belknap Press of Harvard University Press.

[6] Wever, S. D. etal., 2005. The impact of trust on strategic resource acquisition through interorganizational networks: towards a conceptual model. Human Relations, 58(12), p.1523-1543.

[7] Putnam, R. D., 1995. Bowling alone: America's declining social capital. Journal of Democracy, 6(1), p.65-78.

[8] Leana, C. R., and Buren, H. J. V., 1999. Organizational social capital and employment practices. Academy of Management Review, 24(3), p.538-555.

[9] Nahapiet, J., and Ghoshal, S., 2000. Chapter 6 - social capital, intellectual capital, and the organizational advantage *. Knowledge \& Social Capital, 23(2), p.119-157. 
[10] Labianca, G., and Chung, M. H., 2006. A multilevel model of group social capital. Academy of Management Review, 31(3), p.569-582.

[11] Adler, P. S., 2002. Social capital: prospects for a new concept. Academy of Management Review, 27(1), p.17-40.

[12] Knight, F. H., 2013. Risk, uncertainty and profit. Vernon Press Titles in Economics(4), p.682690.

[13] Mair, J., 2001. Entrepreneurial behavior in a large traditional organization : exploring nature, drivers, and performance implications. European Conference on Artificial Intelligence.

[14] Ning, A. N., and Wang, H. Q., 2011. Prior experience,entrepreneurial learning mode and new technology venture performance —an empirical study from the perspective of initial condition. Journal of Business Economics,(9), p.34-42.

[15] Covin, J. G., and Slevin, D. P., 1991. A conceptual model of entrepreneurship as firm behavior. Social Science Electronic Publishing, 16(1), p.7-25.

[16] Cooper, A. C. etal., 1994. Initial human and financial capital as predictors of new venture performance. Journal of Business Venturing, 9(5), p.371-395.

[17] Murphy, G. B. etal., 2004. Measuring performance in entrepreneurship research. Journal of Business Research, 36(1), p.15-23.

[18] Chrisman, J. J. etal., 1998. The determinants of new venture performance: an extended model. Entrepreneurship Theory \& Practice, 23(1).

[19] Rong Li., 2007. Research on the entrepreneurial performance of structure model and effectiveness evaluation. Zhejiang University.

[20] Cao, Z. R., and Cao, N. N., 2011. Entrepreneurship performance structural model: based on the modification of entrepreneurship performance measurement theory. Commercial Research.

[21] Lusheng Fang., 2010. Research on the entrepreneurial Capital and entrepreneurial performance in small micro-enterprise. Northwestern University.

[22] Xin Chen.,2010. The influence of entrepreneur human capital and social capital on entrepreneurial performance in small micro-enterprise. Shandong University.

[23] Chen, Q. Q., and Zheng, T. X., 2017. An empirical study of relationships between elements of university students' entrepreneurial ability and entrepreneurial performance. Journal of Higher Education. 